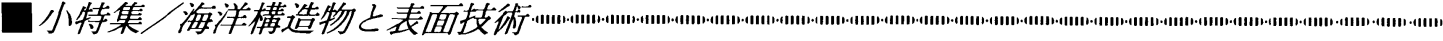

\title{
チタンクラッド鋼による海洋構造物の防食技術
}

\author{
田所 裕 ${ }^{*}$, 本間 宏二*, 長谷 泰治*
}

\section{A Corrosion Protection Method of Marine Structures with Titanium Clad Steel Plates}

\author{
Yutaka TADOKORO*, Koji HOMMA* and Taiji NAGATANI*
}

Key Words : Titanium, Titanium Clad Steel, Splash Zone, Maintenance Free, Aesthetic Appearance

\section{東京湾横断道路鋼製橋脚の 100年耐久性を確保} するために開発された，優れた耐海水腐食性を有 するチタンクラッド鋼板による飛沫，干満部の新 しい防食技術について解説する。

\section{1.はじめに}

内需拡大の動きもあって大型鋼構造物の建設需 要は根強いあのがある。この中にあって, 恒常的 な人手不足からくるメンテナンスフリーの要請, さらに構造物の長寿命化二ーズから, 超長期を目 標とした防食法がますます強くのぞまれている。 この目的のために, 従来, 50年程度の寿命を一つ の目安に高分子材料のライニングによる重防食技 術が種々開発されてきた。しかし一般に高分子材 料は長い期間に光や空気によって劣化し，100年 程度の寿命を考えたときには，さらに高信頼性の 材料が必要となってくる。この点から最近，高耐 食性金属によるライニング防食が注目されてきて いる。

\section{2.チタンおよびチタンクラッド鋼板}

チタンは20世紀中頃に工業生産が開始された

* 新日本製鐵(侏)鉄鋼研究所（干299-12 千葉県富津市新 富20-1)

Nippon Steel Corp. Steel Research Lab. (20-1, Shintomi, Futtsu-shi, Chiba 299-12)
新しい金属素材であり，耐食性はきわめて優れて いる。この耐食性は各種の化学プラントや温泉で の熱交換器などで実証されているが，なかでも海 水に対する耐食性は強固な不動態皮膜によって白 金と同等である。事実，建設省土木研究所と鋼管 杭協会や鋼材俱楽部が千葉沖や大井川沖で実施し た実海洋暴露試験でも腐食は全く認められず，ス テンレス鋼やモネルなどにみられる孔食や隙間腐 食も全く発生していない。また貪い錆からの腐食 の発生, 溶接部, 溶接熱影響部からの腐食発生の 心配もない。

この特性を利用して, 臨海発電所の海水冷却に よる復水器や海水淡水化プラントで数多く使用さ れており，これらの20年近い追跡調査でも腐食 は全く認められていない。

チタンの物理的特性としては, 比重は 4.51で 鋼の約 $60 \%$, 熱膨張は普通鋼，ステンレス鋼と 比較して小さく，ヤング率は鋼の $50 \%$ と小さい などの特徴を有している。またその強度は酸素量 によって JISで 1 種〜 3 種に分類されるが， 275 〜 $618 \mathrm{~N} / \mathrm{mm}^{2}$ と普通鋼とほぼ同じである。

このようにチタンは耐海水腐食性に非常に優れ ている。しかし, 海洋構造物の防食に使用するに は, 解決すべき課題としては大きく 2 つ考えられ る。

まず第一に，いかにチタンと鋼構造物を接合す るかといった接合法の問題である。ステンレス鋼 やモネルなどが鋼と直接溶接が可能であるのに対 




図1 東京湾横断道路の鋼製橋脚（予想図）

し，チタンは鉄と直接溶接すると脆い金属間化合 物を形成するため，実用的には鋼と直接溶接する ことはできない。このため，チタンと鋼を一体化 したチタンクラッド鋼板を活用し，クラッド鋼の 鋼部分と鋼構造物の本体を溶接接合し，表面のチ タン部分を防食ライニングとする方法が考えられ る。

第二はコストの問題である。従来, チタンクラッ ド鋼板は厚板しか製造されておらず，このような ライニングに使用するには板厚の面で無駄が多く, その製造方法では素材自体が高価であった。チ夕 ンクラッド鋼板の製造方法には，従来真空中でチ タン板と鋼板を重ねたスラブ組立をおこない，酸 化物の生成を防止して圧延する真空圧延法，およ び火薬の爆発力によりチタン板と鋼板を常温で機 械的に接合する爆着法がおこなわれてきているが, いずれも製造にかかるコストが大きい。最近，チ
タン板と鋼板の間に銅板を挾み，大気中でスラブ を組立て，普通鋼製造プロセスで熱間圧延された 低コストのチタンクラッド鋼板が開発された。こ の製造法の特徵は, 生成した酸化物を, 低融点で 液状になった銅とともに熱延しながら絞り出す点 である。この製造技術によれば，耐海水ステンレ ス鋼などの高級高耐食ステンレス鋼なみのコスト でチタンクラッド鋼薄板が製造でき，海洋土木分 野において防食被覆材としてチタンクラッド鋼板 が使用可能な状況となった。

\section{3. 東京湾横断道路橋梁部の防食法}

東京湾の中央部，川崎と木更津間約 $15 \mathrm{~km}$ を結 ぶ東京湾横断道路（図 1 ） は木更津側約 $5 \mathrm{~km}$ が 橋梁で, その沖合部 (水深 $20 \mathrm{~m}$ ) は航路確保と 現地での工事期間の短縮のため, 関西空港の連絡 橋と同様に水中基礎工法が採用されている。

海洋に設置するという厳しい腐食環境にもかか わらず，重要な社会資本であるため耐用年数は $50 \sim 100$ 年が目標とされ，最新の防食技術の実施 が要求された。

大気中部分の防食は厚膜エポキシ樹脂塗装+フッ 素樹脂塗装であり, 海中部はタールエポキシ樹脂 塗装＋犠牲陽極による電気防食法で，いずれも補 修を前提としている。

その両者の接点である飛沫, 干満部では補修が 不要で, 流木や小型船舶などの衝突に耐え, さら に日本の表玄関としての景観を考慮したメンテナ

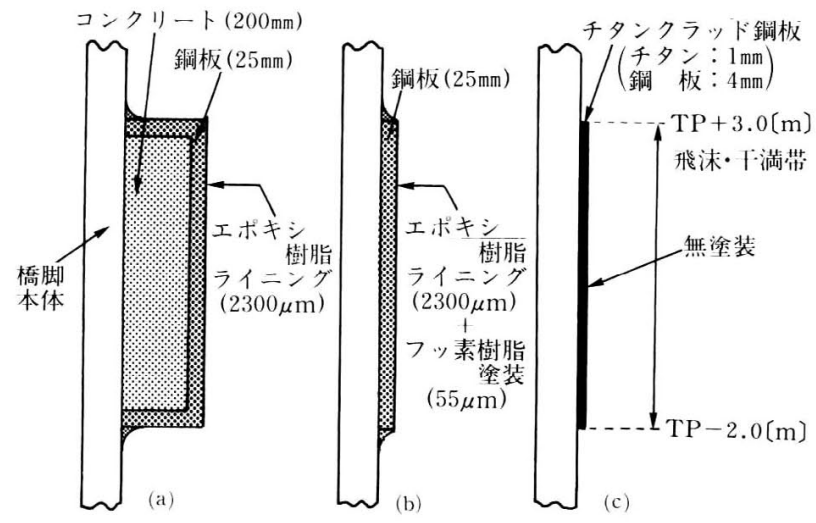

図 2 飛沫・干満帯の 100年対応の防食法 
ンスフリーの防食法が強く要請された。

これまでの超長期の飛沫, 干満部防食法として, 関西空港連絡橋で採用された図 2 (a) の方法は, 樹脂ライニングで 30 年, 犠牲鋼板 $(25 \mathrm{~mm})$ の腐 食しろで 55 年, コンクリートで 15 年の計 100 年 の耐食を期待する方法である。図 2 (b) の方法は 景観対策から提案されたもので, フッ素樹脂塗装 と, 樹脂ライニングで 40 年, 犠牲鋼板で 60 年を 期待する方法である。

これらに対し，図 2 (c) がチタンクラッド鋼板 による方法で, チタンクラッド鋼薄板を溶接ライ ニングし, 表面のチタンで飛沫, 干満部を防食す る。チタンの耐海水腐食性から 100年にわたる防 食が期待できるととあに，金属ライニングのため 耐衝撃性にも優れ，かつ表面も滑らかで景観上か らも好ましい方法といえる。

ここで使用されるチタンクラッド鋼板は, 異物 の衝突による耐衝撃性, 曲げ加工性, 溶接性など について充分な特性を有する, チタン $1 \mathrm{~mm}$, 鋼 $4 \mathrm{~mm}$, 合計 $5 \mathrm{~mm}$ 厚の大気中圧延法により製造 されたクラッド鋼板である。ここにおけるチタン は, 耐食性, 機械的性質, 施工性などから考慮さ れた JIS規格 1 種材である。

さらに, チタンクラッド鋼板を鋼構造物被覆防 食材として適用するには，以下に述べる利用技術 課題を解決することが前提となる。

(1) チタンクラッド鋼板の橋脚本体への接合法お よびクラッド鋼板継目端部シール法

(2) チタンと橋脚本体との異種金属接触腐食の防 止法

（3）チタン表面の塗装法

(4) チタンクラッド鋼板被覆防食法の長期防食性 能の確認

チタンクラッド鋼による海洋構造物の防食法は 初の試みであり, 以下に東京湾横断道路(株)と新 日本製鐵(制が共同開発した防食技術について述 ベることとする。

\section{4. チタンクラッド鋼板の接合法と端部シー ル溶接施工法}

チタンクラッド鋼板を橋脚本体へ取り付けるに

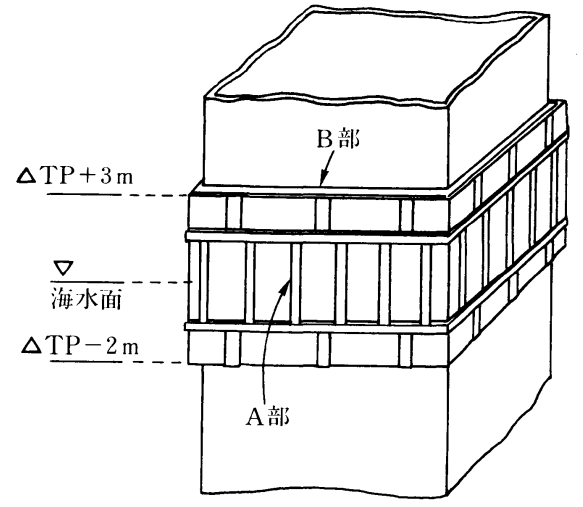

図3チタンクラッド鋼板の配置図
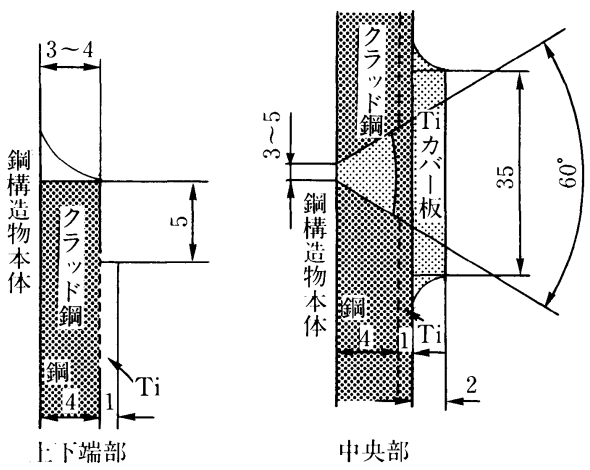

図4本体鋼構造物とチタンクラッド鋼板の溶接法

際しては, チタンクラッド鋼の端部の異材溶接が 必要不可欠になる。そのために上・下段部を図 3 に示すように“はちまき状”にチタンクラッド鋼 を配置し異材継手部を極力少なくした施工法とし た。

図 4 に鋼構造物本体との接合を示す。チタンク ラッド鋼板の上下端部（飛沫部および海中部）は, チタンクラッド鋼のチタンと鋼材とが融合し脆化 相が形成されるのを避けるため, クラッド鋼のチ タン部分を $5 \mathrm{~mm}$ ほど切り欠き，クラッド鋼板の 鋼材部 $4 \mathrm{~mm}$ 之橋脚本体の鋼材を TIG溶接した。 クラッド鋼の突き合せ部 (中央部) では, 開先を, $60^{\circ}$ とし，ルートギャップを $3 \sim 5 \mathrm{~mm}$ とし同質 の溶加材を添加して橋脚本体の鋼材に取り付けた。 その際，入熱を少なくし，スパッ夕などによるチ タン面への損傷を防ぐために TIG溶接をおこなっ 


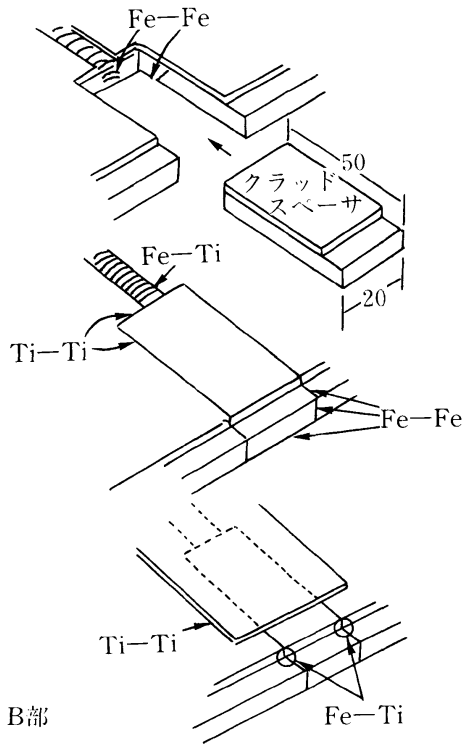

図 5 上下端部クラッドスペーサの溶接部分

た。また，鋼一鋼溶接部を表面に露出させないた め $2 \mathrm{~mm}$ 厚, $35 \mathrm{~mm}$ 幅のチタン薄板で覆い, クラッ ド鋼のチタン部分と TIG溶接（隅肉またはなめ付 け）によりカバーした。

しかし, チタンクラッド鋼の端部溶接部分（図 3 の B 部）は隙間構造となり, 海水中で毛細管現 象により, 継手部は海水に浸されクラッド鋼の母 材部分が腐食される。よって, 隙間部を完全密封 することが必要である。ただし，その部分は異材 溶接となることから特に施工法に工夫が必要であ る。チタンと鋼の異材溶接部を最小限にするため, 上下端部は，図 4 の開先形状とし，および図 5 に 示すクラッドスペーサを挿入し，接合部が線状に なるようにして Ag-Cu-Snを主成分とした溶材を 用いTIG溶接により密封した。

\section{5．異種金属接触腐食とその防止法}

おおよそ海水中において，チタンやステンレス 鋼などの普通鋼より高い電位の金属が接触すると, 普通鋼の腐食が早められる現象，すなわち異種金 属接触腐食がみられる。

チタンクラッド鋼板は鋼製橋脚と溶接接合され た後, 橋脚本体の普通鋼露出部全面を塗装すれば 異種金属接触腐食はおこりにくい。しかし長時間

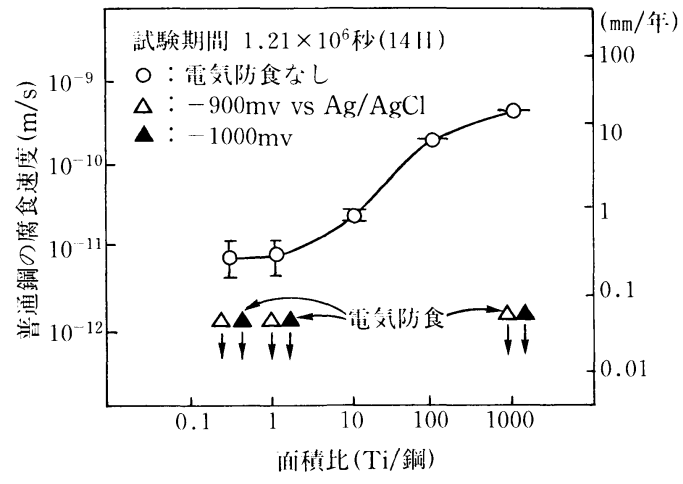

図 6 人工海水中におけるチタンと鋼の異種金属接触 腐食および電気防食の効果

経過後には，(1) 塗装の局部的はく離，(2) 流木や 船舶の衝突による表層チタン板の損傷，などによ り普通鋼が露出する状況がおこりえないとはいえ ない。また，その状況においてチタンと炭素鋼の 露出面積の比率によっては普通鋼の腐食がかなり 早められ，橋脚の耐用年数が著しく低下すること が懸念される。そのため, 異種金属接触腐食の防 止対策を施す必要がある。そこで，チタンクラッ ド鋼板がライニングされる飛沫部，干満部，海中 部の腐食環境を模擬した室内試験により異種金属 接触腐食現象を把握し, 防食対策として従来海洋 鋼構造物の防食に用いられてきた流電陽極法によ る防食効果について評価した。その結果, 図6に 示すように海中部においては，チタン／普通鋼の 面積比が増大するに伴って腐食速度の大きな増加 がみられたが，電気防食によって，異種金属接触 腐食が防止できることがわかった。

また，電気防食の効果は干満部においてもみら れ，万一の事故によりチタン面に局部的な破損が 生じても海中の電気防食の効果により腐食が抑制 されることを確認した。また，飛沫部においては， チタンとの接触において特に鋼の腐食が促進され ることがないことがわかった。

また，チタンクラッド鋼ライニングの上端部す なわち大気中のチタンと鋼の接点においては, 上 部の大気にさらされている鋼部分へのエポキシ樹 脂塗装十フッ素樹脂塗装をチタン部分の上に 250 $\mathrm{mm}$ 重ね塗装することにより端部を保護する方法 とした。 


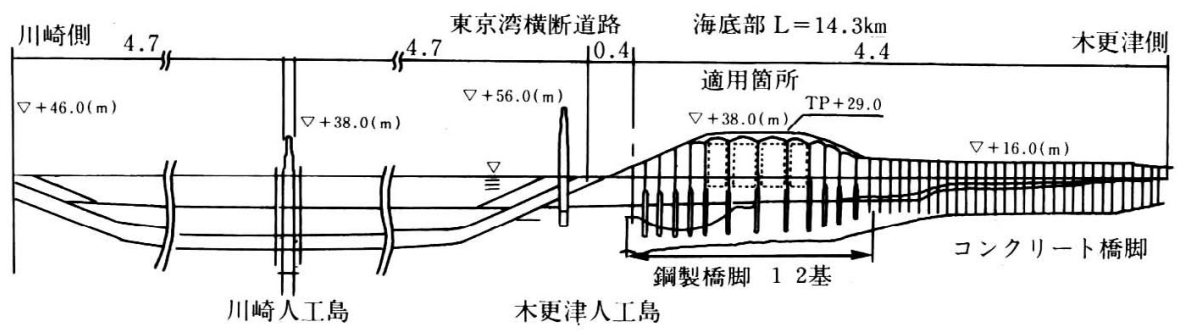

図 7 東京湾横断道路の概要

さらに海中部の異種金属接触腐食の防止につい ては電気防食が不可欠であるため, チタンと鋼が 共存する複雑な形状の実構造物において, 儀牲陽 極の数量および配置に関し, どのように電気防食 設計すればよいかについて数値解析によるシミュ レーションを行い, 実構造物における電気防食設 計指針を確立した。

\section{6. チタンクラッド面への塗膜の密着性}

一般にはチタンはその優れた耐食性から塗装せ ずに用いられるが，チタンクラッド鋼ライニング として使用する場合は普通鋼とチタンとの境界部 の防食及び景観から構造物に着色するために塗装 することが必要となる。

そこで, 新たにチタンへの塗装仕様について検 討をおこなった。塗装仕様として, 素地調整を鋼 面と同様なサンドブラスト処理し，エポキシ樹脂 塗料を下塗りとし, 表面をフッ素樹脂塗料とし, その一次物性（塗装後 $20^{\circ} \mathrm{C} 7$ 日間養生），二次物 性（ $40^{\circ} \mathrm{C} 3 \%$ 食塩水に 1 ケ月〜 1 年浸せき）を共 に碁盤目試験, アドヒージョン試験により評価し たところ, チタンと鋼の密着性差は認められず, 良好な密着性が得られることがわかった。

\section{7. 海洋暴露試験による長期特性の検証}

以上の室内試験の結果から，チタンクラッド鋼 を適用するにあたって，チタンと鋼が接する境界 部やチタンが万一損傷を生じた部分に対して, 異 種金属接触腐食の防止策が必要であり, その方法 として, 海中部および干満部では電気防食が有効 であることが示唆された。また, 飛沫部では異種
金属接触腐食の影響は小さいこと，および，チ夕 ンへの塗膜付着性も確保されることから, 塗装の 適用が可能であることが示された。

しかしながら, 実構造物への適用には, 構造物 レベルでの実際の海洋環境における性能の確認が 必要である。そこで, チタンクラッド鋼板によっ て被覆した鋼管杭を平成 2 年 4 月より 5 年間の予 定で，横断道路の計画に隣接する新日本製鐵(株)君

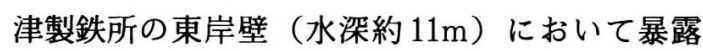
し，綿密な観察ととあにチタン表面の電位，儀牲 陽極発生電流などの経時変化を測定し防食性能の 確認を行っている。1 年経過後の調查において腐 食, 塗膜劣化など全くなく，100年耐用に向けて の予想通りの防食性能を示している。

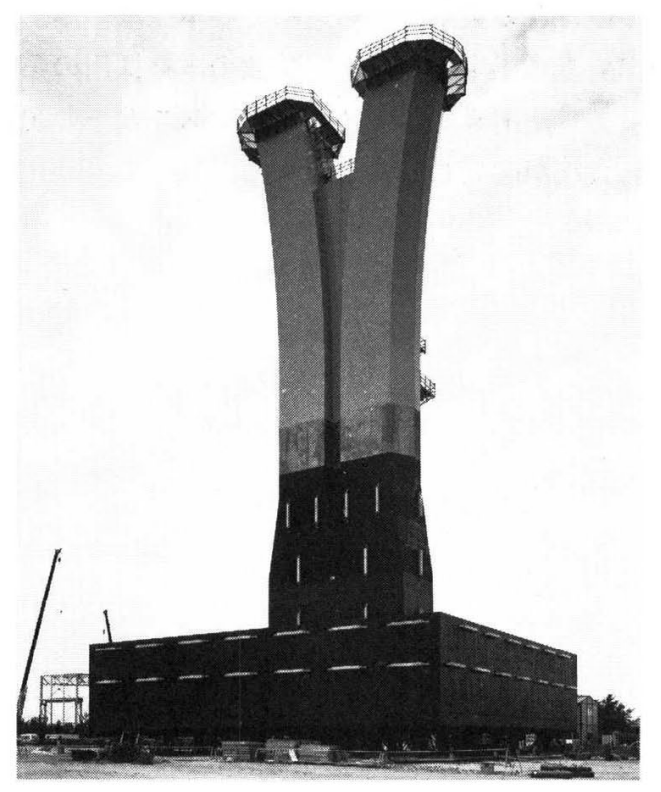

図8チタンクラッド鋼板による防食被覆を施した東 京湾横断道路鋼製橋脚 


\section{8. 東京湾横断道路鋼製橋脚への適用}

以上，チタンクラッド鋼ライニングについて, その接合技術，異種金属接触腐食防止技術，塗装 技術の検討に加え, さらに海洋暴露試験を行い, 実用化への目処を得たことから，東京湾横断道路 の鋼製橋脚へ採用されることとなった。適用䇢所 は図 7 に示すように木更津人工島と木更津を結ぶ 橋梁の沖合い部鋼製橋脚で全 12 基である。鋼製 橋脚は図 8 に示すような脚柱とフーチング部から 成るあので一基あたり 1000〜2000トンに達する （橋脚ごとに異なる）。この鋼製橋脚を予めファブ リケーションャードで製作し，チタンクラッド鋼 ライニング, 電気防食用儀牲陽極取付, 塗装など の防食措置を行った後, フローティングクレーン により現地へ曳航し，予め打設した鋼管杭上に設 置し，水中不分離性コンクリートにより結合する 方式をとっている。平成 4 年 6 月現在では，鋼製 橋脚 3 基が完成し（橋脚番号 P 7 ; 図 8, P10, P 8 ）現地据え付けを完了している。

\section{9.おわりに}

このたびの東京湾横断道路での本工法の施工は 海洋, 土木工事へのチタン防食の本格採用の第一 歩であり，鋼構造物のメンテナンスフリーの超長 期防食法が開発されたといえる。
このチタンクラッド鋼薄板によるライニング法 以外にも，有機防食材（ペトロラタム）との複合 防食法が既設鋼管杭の飛沫, 干満部の防食法とし て, 平成 2 年に北九州港門司地区で施工された。 さら大気中の防食法としてチタン箔（厚さ 100 $\mu \mathrm{m}$ ）と粘着材との複合による鋼構造物やコンク リート構造物の防食についての暴露試験が開始さ れている。

このようにチタンを使ったメンテナンスフリー を目指す海洋構造物の超長期防食技術の開発には, 大きな期待が寄せられつつある。その防食技術に おいては，チタン素材の加工・施工法および異種 金属接触腐食の防止がポイントとなると考えられ る。これらはまだ新しい技術であり，今後実績と とあに評細な技術指針の確立が急がれるところで ある。さらに超長期防食のためには単に材料に依 存するのみならず，自動腐食モ二タ一の開発など 周辺技術の完備も企ててこそ高信頼性の技術とな るあのと考える。

最後に本防食技術についてのさらに詳細な報告 については，参考文献を参照していただきたい。

(1992-7-2 受理)

\section{文献}

1) 香川祐次, 中村俊一; 土木学会論文集, No.435/VI15, p.69-77, p.79-87 (1991) 